\title{
SARIKAT ISLAM DALAM PERGERAKAN NASIONAL INDONESIA (1912-1927)
}

Oleh: Yasmis

Dosen Jurusan Sejarah FIS UNJ

\begin{abstract}
Abstrak
Pergerakan nasional Indonesia dimulai pada awal abad ke-2o dengan munculnya beberapa organisasi modern. Salah satunya adalah Sarekat Islam. Organisasi ini bermula dari sebuah perkumpulan para pedagang batik untuk mengimbangi kemajuan para pedagang batik Cina. Keanggotaannya terus berkembang hingga tidak terhadap para pedagang batik saja, tetapi seluruh bangsa Indonesia yang beragama Islam sehingga Sarekat Islam berkembang menjadi sebuah organisasi modern yang paling banyak anggotanya. Tulisan ini mengulas tentang keberadaan Sarekat Islam dalam pergerakan nasional Indonesia.
\end{abstract}

\section{Pendahuluan}

Penjajahan mempunyai dua sisi, yaitu kesengsaraan pada pihak yang terjajah dan kemakmuran pad pihak yang menjajah. Kedua pihak tersebut berhadap-hadapan sebagai lawan. Pihak yang pertama berusaha inigin membebaskan diri ditandai dengan munculnya sekelompok orang yang mempelopori usaha untuk melenyapkan penjajahan sedangkan pihak kedua berusaha untuk mempertahankan koloninya sebagai sumber devisa. ${ }^{1}$

Pemerintah Hindia Belanda memasuki daerah Indonesia berlangsung mulai abad ke-17 sampai dengan abad ke-19. Pelakuan diskriminatif pada bangsa-bangsa India, Arab dan Cina terhadap pribumi juga berlangsung pada masa ini. Politik "rasionalisme" menyebabkan manusia

${ }^{1}$ Sartono Kartodirdjo, Sejarah Pergerakan Nasional dan Kolonialisme sampai Nasionalisme Jilid 2 (Jakarta: Gramedia Pustaka Utama, 1993), hal. 6. digolong-golongkan menjadi beberapa golongan dan penduduk asli (Indonesia) ditempatkan sebagai ras terbawah dalam status sosial masyarakat. ${ }^{2}$

Pemerintah Hindia Belanda semakin memperluas kekuasaannya mencakup berbagai segi kehidupan baik politik, ekonomi dan sosial budaya. Dalam bidang politik, pemerintah Hindia Belanda ikut campur secara intensif dalam persoalan-persoalan intern Indonesia seperti ikut menentukan kebijaksanaan-kebijaksanaan politik rakyat. Dalam bidang ekonomi pemerintah Belanda membuat suatu kebijakan "memeri kebebasan berdagang bagi orang-orang Cina". ${ }^{3}$ Kedudukan Cina dalam struktur ekonomi pada waktu itu adalah sebagai

\footnotetext{
${ }^{2}$ Abu Hanifah, Renungan Perjuangan Bangsa Dulu dan Sekarang (Jakarta: Yayasan Idayu, 1978), hal. 8, 9, 10.

3 Poespoprodjo W, Jejak-jejak Sejarah 19081928. Terbentuknya Suatu Pola (Bandung: Remaja Karya, 1986), hal. 8
} 
pedagang perantara antara Belanda dan Pribumi dengan fasilitas istimewa, sehingga tidak mengherankan jika Cina berhasil menguasai hampir seluruh ekomoni rakyat, seperti memonopoli bahan-bahan batik. Posisi ini membuat Cina dirasuki kesombongan luar biasa. Kesombongan ini bertambah menjadijadi setelah revolusi Cina. ${ }^{4}$ Melihat keadaan tersebut akhirnya menimbulkan perlawanan melenyapkan penjajahan dari bumi Indonesia. Perlawanan-perlawanan itu sifatnya sporadis dan berakhir dengan kegagalan.

Belajar dari kegagalan-kegagalan itulah muncul kesadaran di antara para pejuang Indonesia, bahwa dengan mengandalkan fisik belaka, kebebasan tidak mungkin dapat dicapai. Maka, muncullah perkumpulan-perkumpulan atau organisasi-organisasi untuk melawan penjajahan baik secara politik, ekonomi maupun sosial budaya. Salah satu perkumpulan tersebut adalah Sarekat Islam (SI) bermula dari Sarekat Dagang Islam (SDI). Sarekat Islam lahir tahun 1912 di Solo yang dipelopori oleh H. Samanhudi, bergerak di bidang sosial ekonomi rakya, dan juga pada bidang politik.

Sarekat Islam bertujuan untuk memajukan perdagangan, memberikan pertolongan kepada anggota-anggota yang kesusahan, baik jasmani maupun rohani, memajukan kehidupan agama Islam, dan berjuang menuntut pemerintahan sendiri. Dalam perjuangannya, Sarekat Islam mendapat tempat di hati rakyat. Anggota Sarekat Islam telah meluas sampai ke pelosok tanah air, sehingga Sarekat Islam dinamakan organisasi

\footnotetext{
4 A. K. Pringgodigdo, Sejarah Pergerakan Rakyat Indonesia (Jakarta: Dian Rakyat, 1980), hal. 4 .
}

messa rakyat yang pertama di Indonesia. Pergerakan Sarekat Islam lebih mementingkan rakyat banyak dari pada kepentingan golongan. Sarekat Islam dalam pergerakannya senantiasa menentang imperialisme dan kapitalisme dalam segala bentuk, karena itu Sarekat Islam berusaha mencegah timbulnya kapitalisme dan imperialisme. Untuk mempercepat tercapainya tujuan Indonesia merdeka, Sarekat Islam bergabung dengan partaipartai politik lainnya. Dengan kondisi yang demikian itu, Sarekat Islam turut ambil bagian dalam percaturan politik, ekomoni dan sosial budaya yang sangat besar di dalam pergerakan nasional Indonesia.

\section{Lahirnya Sarekat Islam}

Kolonial Belanda beserta sistem eksploitasinya telah menimbulkan keresahan. Ketimpangan yang diraskan sangat menyinggung rasa harga diri pribumi. Pribumi tidak boleh memakai bahasa tinggi terhadap atasan, pribumi dilarang memakai pakaian modern (Barat), pribumi diharuskan bersial di lantai. ${ }^{5}$ Sikap diskriminatif yang dilaksanakan kolonial Belanda terhadap pribumi akhirnya menimbulkan pergolakan dalam masyakat. Ketidakadilan yang diterima oleh pribumi telah membangkitkan kesadaran yang akhirnya menimbulkan pergerakan nasional.

Pergerakan nasional adalah usahausaha yang dilakukan oleh rakyat untuk melepaskan diri dari penjajah. Salah satu pergerakan nasional itu adalah Sarekat Islam. Sarekat Islam didirikan atas pertimbangan komersil ekonomis dengan azas nasionalisme yang

${ }^{5}$ Sartono Kartodirdjo. Op. Cit., hal. 108. 
sepenuhnya merupakan haluan politik Sarekat Islam.

Guna memperoleh gambaran awal dirasa perlu mengemukakan kondisi perdagangan yang berkembang pada awal abad 20 yang mana keadaan sosial ekonomi masyarakat Indonesia memperlihatkan gambaran yang menyedihkan. Prinsip ekonomi liberal yang dijalankan mulai tahun 1870 dan berlangsung selama lebih kurang 20 tahun, telah memberikan keuntungan yang besar kepada para pengusaha swasta Belanda dan Eropa lainnya.

Sistem ekonomi liberal yang telah memberikan keuntungan kepada pengusaha-pengusaha swasta mengalami kehancuran. Hal ini disebabkan dalam tahun 1885 terjadi krisis ekonomi yang disebabkan menurunnya harga tanaman di pasaran dunia. Akibatnya pada awal abad 19 terjadi kebijakan baru dalam pengaturan ekonomi Hindia Belanda, yaitu liberal yang mengutamakan usaha swasta dan persaingvan bebas akhirnya ditinggalkan dan diganti dengan tata ekonomi baru yang lebih bersifat terpimpin. ${ }^{6}$

Perubahan tata ekonomi tersebut tetap tidak membawa perbaikan terhadap soaial ekonomi penduduk Indonesia bahkan sebaliknya semakin merosot dan perusahaan pribumi semakin mundur, kepentingan pribumi baik materil maupun spiritual tidak diperhatikan pemerintah Belanda. Keadaan bertambah buruk ketika awal abad 20 panen gagal akhirnya menyebabkan paceklik. Kenyataan ini terlihat dari penurunan jumlah barangbarang import, seperti tekstil, bahan makanan dan sebagainya.

\footnotetext{
${ }^{6}$ Nugroho Notosusanto, Djoned Poespoprodjo, Marwari. Sejarah nasional Indonesia Jilid $V$ (Jakarta: Balai Pustaka, 1966), hal.9o.
}

Dalam situasi ekonomi rakyat yang semakin merosot pada awal abad 20 orang-orang Cina telah dapat menguasai hampir seluruh ekonomi masyarakat Jawa.

"Adapun beberapa hal yang
mendorong keberhasilan orang-
orang Cina tersebut yakni selain
kebijakan yang diberikan
pemerintah Hindia Belandajuga
karena kelebihan orang-orang Cina
tersebut sebelum berimigrasi ke
Indonesia atau ke luarjangkauan
daerahnya, orang-orang Cina
kompak dan memiliki satu kerjasama
secara gotong-royong dalam bidang
ekonomi, serta kegiatan dagang
mereka didasarkan kepada
kelompok-kelompok kekerabatan
juga bahasa".7

Dalam pemerintah Hindia Belanda perdagangan yang berskala besar ditangani oelh pemerintah Belanda sendiri, sedangkan yang berskala menengah ada di tangan para pedagang Cina. Mereka mendapat kepercayaan dari pemerintah Belanda untk "menangani" segala kebutuhan pemerintah Hindia Belanda, karena itu perlu kiranya diadakan identifikasi unsur Cina yang terbukti talah sanggup merangsang kekuatan-kekuatan tersembunyi pada awal abad 20 itu. ${ }^{8}$

Orang Cina merupakan kelompok pedagang menengah, dan pedagang Jawa tergolong pedagang kecil tetapi berada dalam kelompok besar yang tersebar sampai di pelosok daerah Jawa. Orang Cina adalah pedagang migran, kerena itu meskipun mereka jauh dari tanah airnya, namun mereka tidak pernah melepaskan hubungan dari

\footnotetext{
${ }^{7}$ Leirissa, R. Z. Terwujudnya Suatu Gagasan Sejarah Masyarakat Indonesia 1990-1950. (Jakarta: Akademi Presindo, 1985), hal. 37

${ }^{8}$ Abu Hanifah, Op. Cit., hal.17.
} 
tempat asalnya. Kejadian-kejadian di Tiongkok merangsang reaksi Cina di Indonesia. Mereka mendirikan perkumpulan nasionalisme Cina di Belanda pada tahun 1990 yang bertujuan untuk menyatukan orang Cina yang masih provinsialistis.

Pada mulanya kegiatan orangorang Cina agak terbatas, mereka tidak diizinkan berdagang di kampungkampung tanpa seizin pemerintah Belanda. Oleh karena orang-orang Cina sangat dibutuhkan dalam perdagangan hasil-hasil industri Belanda di daerahdaerah pedalaman maka, pemerintah Belanda kembali memberi izin bebas berdagang bagi pedagang-pedagang Cina menanamkan modalnya di desadesa. Ekspansi orang-orang Cina bertambah besar dengan cara mereka ikut menanamkan modalnya di industriindustri lokal. ${ }^{9}$

Kebijakan-kebijakan yang diberikan oleh pemerintah Belanda, dipergunakan dengan sebaik-baiknya oleh para pedagang Cina, sehingga membuat orang-orang Cina bersikap demonstratif. Mereka praktis menguasai perekonomian bangsa Indonesia.

Perluasan perdagangan yang dilakukan oleh orang-orang Cina dirasakan juga oleh pedagang batik di Indonesia, khususnya di kota Solo (Surakarta), mereka juga merasakan tekanan ekonomi dari pihak orangorang Cina. Hal ini sangat dirasakan oleh orang-orang pribumi yang mempunyai perusahaan batik, karena bahan batiknya harus dibeli dari pedagangpedagang Cina. Seperti kita ketahui bahwa impor bahan-bahan batik dilakukan oleh pedagang-pedagang

${ }^{9}$ Robert van Neil. Munculnya Elit Modern Indonesia. (Jakarta: Pustaka Jaya, 1984), hal. 121.
Belanda dan Eropa lain. Dari mereka, barang-barang itu kemudian disalurkan kepada rakyat melalui bangsa Timur Asing (vreemde Oosterligen) yakni Cina dan Arab, tetapi sebagian besar pedagang-pedagang perantara ini adalah orang-orang Cina. Mereka berhasil mempengaruhi harga dan pemasaran pada tingkat terakhir yakni penyaluran. Selain sebagai penyalur bahan-bahan dari pedagang-pedagang Eropa, pedagang-pedagang Cina juga mempunyai perusahaan pembatikan. Karena posisi dagangnya inilah mereka dapat membeli bahan-bahan langsung dari importir dengan harga yang murah. ${ }^{10}$

Sebaliknya pengusaha-pengusaha Indonesia yang harus memikirkan pemasaran juga hasil produksinya, harus membeli bahan dari pedagang-pedagang Timur Asing, khususnya Cina dengan harga yang sangat mahal. Akibatnya harga pembuatan batik mlik pengusahapengusaha Jawa ini lebih tinggi daripada harga batik dikuasai oleh kelas pemasran menengah yakni Cina. ${ }^{11}$ Sehingga dengan sendirinya pedagang Cina dapat menekan harga batik milik perusahan-perusahaan Indonesia/ pribumi.

Ternyata memang sebagian besar perusahaan batik Indonesia telah banyak yang jatuh ke tangan-tangan orang-orang Cina. Di kota-kota besar seperti Bandung, Jakarta dan Semarang tidak lagi dikerjakan batik halus atau batik tulis tetapi batik cap atau batik kasar. Melihat kondisi yang tidak menguntungkan ini, maka H. Samanhudi seorang pengusaha dan pedagang batik

\footnotetext{
${ }^{10}$ Slamet Mulyana. Nasionalisme Sebagai Modal Perjuangan Bangsa Indonesia. (Jakarta: Balai Pustaka, 1968), hal. 200.

${ }^{11}$ Poespoprodjo. Op. Cit., hal. 42-45
} 
dari Surakarta, menyadari bahaya yang semakin mengacam yaitu semakin besarnya pengaruh Cina di bidang perekonomian ditambah dengan besarnya peluang-peluang yang diberikan pemerintah Belanda kepada pedagang Cina berupa keringanankeringanan, dibanding kepada pedagang-pedagang Indonesia sendiri. Hal ini dirasakan sangat tidak adil, dan sangat menghambat kemajuan perdagangan pribumi pada umumnya dan pedagang batik khususnya.

H. Samanhudi berusaha memperbaiki keadaan untuk itu ia mendirikan sebuah organisasi yang dinamakan Sarekat Dagang Islam (SDI). Mengenai pendirian SDI, banyak pendapat tentang tahun pendiriannya, tetapi H. Samanhudi memberikan keterangannya.

"Dengan ikhlas, untuk kemurnian sejarah pergerakan Indonesia, dengan ini saya terangkan bahwa SDI dilahirkan pada tanggal 16 Oktober 1905, di rumah saya di kampung Sandokan, Solo, dengan delapan orang teman, yaitu: Saudara Sumawardoyo, Wiryotirto, Suwandi, Suporanoto, Jarmani, Zhardjosuwarto, Sukir dan Martodikono". ${ }^{12}$

Tujuan berdirinya adalah untuk menggalang kerjasama di antara pedagang-pedagang Islam demi memajukan perdagangan dan menyaingi pedagang-pedagang Cina.

$$
\text { Serekat Dagang Islam }
$$

dikembangkan di Jakarta pada tahun 1909 oleh R. M. Tirtoadisryo kemudian di Bogor pada tahun 1911.

"Pada tahun 1911, beliau mendirikan pula organisasi yang sama di Bogor,

\footnotetext{
${ }_{12}$ M. Mansyur Amin. Sarikat Islam Obor Kebangkitan Nasional 1905-1944. (Yogyakarta: Kelompok IAIN Sunan Kalijaga, 1996), hal. 29.
}
yang mana kedua organisasi tersebut memiliki satu tujuan yang sama yakni untuk membantu pedagang-pedagang Indonesia dalam menghadapi persaingan dengan orang-orang Cina". ${ }^{13}$

H. Samanhudi dan R. M. Tirtoadisuryo menjalin kerja sama dalam persuratkabaran, kerja sama ini tidak berlangsung lama karena terjadi pertikaian, yang menyebabkan aktifitas SDI menurun. Pertikaian ini terjadi akibat penyalahgunaan dana dan ketidaksesuaian harga surat kabar yang terlalu mahal dari persetujuan semula.

Pertikaian antara R. M. Tirtoadisuryo dengan H. Samanhudi menyebabkan hubungan mereka mulai renggang, sehingga mempengaruhi keberadaan organisasi yang akhirnya hubungan tersebut benar-benar pecah. ${ }^{14}$ Untuk melanjutkan jalannya organisasi agar disahkan oleh Pemerintah Belanda, maka $\mathrm{H}$. Samanhudi mencari orang yang dapat mengorganisir organisasi dagang tersebut.

H. Samanhudi meminta agar H. O. S. Tjokroaminoto untuk bertindak sebagai penyusun organisasi kelompok dagangnya. ${ }^{15}$ H. O. S. Tjokroaminoto pun menyetujui, kemudian ia melakukan membuatan akta hukum organisasi baru yang dinamakan Sarekat Islam. Akta hukum tersebut dibuat atas namanya sendiri pada tanggal 10 September 1912. Dengan demikian SI secara resmi telah dibentuk, Sarekat Islam adalah

\footnotetext{
${ }_{13}$ M. C. Ricklefs. Sejarah IndonesiaModern. (Yogyakarta: Gadjah Mada University, 1992), hal. 252

${ }^{14}$ Robert van Neil. Munculnya Elit Politik Modern Indonesia. (Jakarta: 1984), hal. 127.

${ }^{15}$ Deliar Noer. Gerakan Modern Islam di Indonesia 1900-1942. LP3ES. (Jakarta: 1988).
} 
merupakan salah satu organisasi yang gemilang di Indonesia pada awal kebangkitan nasional.

Perubahan nama dari Sarekat Dagang Islam menjadi Sarekat Islam dimaksud agar supaya keanggotaan perkumpulan tidak hanya terbatas pada golongan pedangng, tetapi diperluas mencakup seluruh kegiatan masyarakat. Pembentukan Sarekat Islam dapat diketahui melalui pengakuan pemerintah Hindia Belanda yang mengatakan bahwa:

"Sarekat Islam sebagai organisasi berbadan hukum setelah H. O. S.

Tjokroaminoto menghadap notaris B.

Tert Kuile di Solo dan ditetapkan pada tanggal 10 November 1912, berdasarkan anggaran dasar Sarekat Islam yang baru, meskipun demikian sebenarnya pengakuan pemerintah Belanda terhadap organisasi tersebut telah berjalan tanggal 14 September 1912."16

Pengakuan inilah yang memberikan peluang pada Sarekat Islam untuk mulai mengembangkan sayapnya bergerak tidak hanya dalam bidang perekonomian, tetapi juga bergeraak di bidang politik dan sosial budaya yang didasari oleh ajaran Islam. Kegiatan organisasi ini selalu berorientasi untuk kepentingan bangsa, negara dan agama.

\section{Perkembangan Sarekat Islam}

Asal usul petumbuhan gerakan politik di kalangan muslim di Indonesia dapat dikatakan identik dengan asal usul dan pertumbuhan Sarekat Islam. Sarekat Islam yang tumbuh dari organisasi yang mendahuluinya yang bernama Sarekat Dagang Islam

\footnotetext{
${ }^{16}$ Amelz. H. O. S. Tjokroaminoto. Hidup dan Perjuangan. (Jakarta: Bulan Bintang), hal.9697.
}

merupakan organisasi yang terkenal dengan gerakan nasionalis, demokratis, religius dan ekonomis. Dalam waktu singkat perkembangan Sarekat Islam telah menyebar ke seluruh lapisan masyarakat.

\section{Sarekat Islam Sebagai Organisasi Massa di Indonesia}

Dalam suasana mulai bangkitnya nasionalisme, Sarekat Islampun terus berkembang, tidak di pulau Jawa saja, tetapi telah menyebar ke berbagai pulau. Sarekat Islam didirikan dengan maksud untuk membela kepentingan pedagang-pedagang Indonesia dari ancaman pedagang Cina. Akan tetapi kenyataannya menunjukkan bahwa kegiatannya lebih luas dari maksud semula. Ia seolah-olah merupakan isyatrat bagi rakyat untuk memuali suatu gerakan melawan semua kepincangan dan ketidakadilan yang menimpa rakyat Indonesia, baik yang datangnya dari pemerintah Belanda, saudagar-saudagar Cina, maupun dari kalangan bangsa sendiri yang bekerja sebagai pegawai pemerintah Belanda.

Melihat tujuan Sarekat Islam yang tercantum dalam anggaran dasarnya, tidak terlihat adanya kegiatan politik, akan tetapi kegiatan organisasi jelas terlihat memperjuangkan hak-hak yang sesungguhnya di bidang politik. Tidak bisa dipungkiri bahwa Sarekat Islam adalah organisasi yang memperjuangkan keadilan dengan gigih serta menekan adanya penindasan dan pemerasan oleh pemerintah Belanda. Menghadapi situasi yang sedemikian hidup dan mengandung unsur-unsur revolusioner, pemerintah Belanda 
mulai bersikap waspada dan mengawasi setiap langkah Sarekat Islam dengan cermat.

Kehadiran Sarekat Islam sangat dinanti oleh masyarakat, karena situasi di dalam masyarakat sendiri waktu itu memenag mengharapkan sekali kehadiran suatu organisasi massa yang tidak bersifat elite untuk menyalurkan aspirasi rakyat Indonesia. Dalam kongres Sarekat Islam pertama diadakan pada bulan Januari 1913 di Surabaya ditegaskan bahwa Sarekat Islam bukan partai politik. Pada kongres di Solo diputuskan pula bahwa Sarekat Islam terbuka untuk bangsa Indonesia. Utnuk menjaga agar Sarekat Islam tetap menjadi organisasi rakyat, dilakukan pembatasan terhadap masuknya pegawai negeri sebagai anggota. "Walaupun begitu karena agama Islam sebagai lembaga persatuan dan bertujuan mempertinggi derajat rakyat, menyebabkan Sarekat Islam tersebar di seluruh Jawa dan pulau lainnya. ${ }^{17}$

Kekuatan yang terhimpun dalam lingkungan Sarekat Islam dan keberaniannya bergerak mengkhawatirkan pemerintah Belanda. Kekhawatiran ini muncul karena sering terjadinya kerusuhankerusauhan anti Cina. Di samping itu juga timbul keributan-keributan yang ditimbulkan oleh agitasi yang dipimpin oleh Sarekat Islam.

Karena kekhawatiran itulah maka tahun 1913 pemerintah mengeluarkan suatu peraturan yang menetapkan bahwa cabang-cabang Sarekat Islam harus berdiri sendiri, hal ini bertujuan untuk memudahkan

${ }_{17}$ A. K. Pringgodigdo. Op. Cit., hal. 20 memonitoring setiap kegiatan yang dapat merongrong pemerintah Belanda. Jadi setiap cabang Sarekat Islam mempunyai badan hukum sendiri-sendiri.

Oleh sebab itu perlu kiranya segera mencari jalan keluar bagi para pemimpin Sarekat Islam dalam memecahkan masalah yang sedang dihadapi di samping itu juga mengusahakan kerja sama yang erat antara Sarekat Islam setempat dengan daerah lain. Dalam suatu pertemuan di Yogyakarta (18 Februari 1914) mereka memutuskan untuk membentuk suatu pengurus pusat yang terdiri dari H. Samanhudi sebagai ketua kehormatan sebagai ketua kehormatan, H. O. S. Tjokroaminoto sebagai ketua dan Gunawa sebagai wakil ketua. Tanggal 14 sampai 27 Juni 1916 diadakan kongres yang ketiga di Bandung yang dinamakan Kongres Sarekat Islam Nasional yang pertama.

Kongres Sarekat Islam Nasional dipimpin oleh H. O. S. Tjokroaminoto. Kata nasional dimaksudkan bahwa Sarekat Islam menuju ke arah persatuan yang teguh dari semua golongan bangsa Indonesia. Dalam kongres ini mulailah menyusun konsep mengenai parlemen baik di tingkat pusat maupun ditingkat daerah. Kenyataan ini memperlihatkan bahwa Sarekat Islam mulai melangkah ke bidang politik.

Pendukung Kongres Sarekat Islam Nasional terdiri dari berbagai lapisan masyarakat yang berbeda latar belakangnya. Perkembangan Sarekat Islam yang semakin memasyarakat menjadi pandu dalam jiwa para anggota dan mendapat tempat di hati semua rakyat dan 
menjadikan Sarekat Islam sebagai organisasi massa pertama di Indonesia.

\section{Masuknya Pengaruh Komunis dalam Sarekat Islam}

Di Indonesia komunis diperkenalkan oleh Hendrio Joshepus Maria Sheevliet, seorang Belanda yang datang ke Indonesia tahun 1913. Ia mulanya bekerja sebagai pemimpin redaksi Hendelsblad Surabaya selama dua bulan kemudian berhenti dan menjadi sekertaris kamar dagang Semarang. Pada tahun 1914 Sheevliet bersama temannya bangsa Belanda yang sepaham di antaranya Adolf Baars mendirikan Indische Social Democratische Vereenihing (ISDV) di Semarang yang bertujuan menybarkan pahampaham Marxis. Anggota ISDV tidak banyak tapi kemudian ISDV berusaha mempengarhui rakyat agar menjadi pengikutnya tetapi tidak mendapat sambutan yang baik karena ISDV tidak terlalu dekat dengan rakyat. Oleh sebab itu mereka mencoba memasuki Sarekat Islam Semarang yang dipimpin oleh Samaun. ${ }^{18}$

Pada kongres Sarekat Islam yang kedua (1917) di Jakarta, Sarekat Islam menegaskan tujuannya yakni akan menuju kemerdekaan. Namun, perumusan tersebut belum dipertegas dan diperjelas sehingga dikhawatirkan akan membawa dampak terhadap Sarekat Islam. Dalam kongres kedua ini juga disinggung masalah Volksraad (Dewan Perwakilan Rakyat) yang sedang dalam

${ }_{18}$ M. Dimyati. Sejarah Pergerakan Rakyat Indonesia. (Jakarta: Wijaya, 1951), hal. 16 pembentukan. Sikap lunak Sarekat Islam terhadap pemerintah Belanda ini dikenal dengan sikap nasionalisme kooperatif.

Samaun tidak setuju bahwa Sarekat Islam mengirimkan wakilnya dalam Volksraad. Samaun mulai melancarkan kritikan-kritikan tajam kepada pemerintah, akan tetapi Sarekat Islam masih tetap menjalin hubungan dengan pemerintah Belanda meskipun harus diakui bahwa sudah masuk pengaruh aliran revolusioner sosialistis dalam tubuh Sarekat Islam. Hal ini terlihat dalam perumusan sebagai berikut:

1. Sarekat Islam dalam azas perjuangan politiknya menuju pemerintahan sendiri (Zelf Bestuur), kata mereka belum berani diperjuangkan.

2. Perjuangan menentang penjajahan dan kapitalisme yang jahat (inilah pengaruh aliran revolusioner sosialistis).

Pengaruh Samaun makin lama makin besar dalam tubuh Sarekat Islam, pada kongres Sarekat Islam ke III (1918) ditegskan dlam kongres bahwa:

"Pertentangan yang besar tidak hanya mengenai pertentangan antara kaum penjajah kontra kaum dijajah saja, akan tetapi juga ditegaskan bahwa di Hindi Belanda pertentangan yang besar juga terdapat antara kapitalis kontra kaum buruh". ${ }^{19}$

Sebagai akibat daripada adanya penegasan ini, maka Sarekat Islam mulai mengorganisasikan kaum

19 M. Sidky Daeng Materu. Sejarah Pergerakan Nasional Bangsa Indonesia. (Jakarta: Gunung Agung, 1996), hal. 25 
buruh dan serikat-serikat pekerja. Pembentukan kaum buruh dan serikat-serikat pekerja di serahakn kepada Sosrokardono, bertepatan dengan kongres ke IV Sarekat Islam. Kongres ke IV Sarekat Islam sangat lesu akibat adanya dua peristiwa perlawanan nasional dari anggota Sarekat Islam, masing-masing di Toli-toli dan Tjimareme dan Garut pada tahun 1919. Pada kongres ini Setia Budi (Dr. Dauwes Dekker) menyampaikan prasarannya dan menyatakan bahwa:

"Jangan menekankan
pertentangan ekonomi antar
kelas, tetapi hendaklah lebih
dahulu ditekankan
pertentangan antar bangsa,
teristimewa antara bangsa
yang dijajah dan bangsa yang
menjajah". ${ }^{\circ}$

Prasaran ini merupakan suatu injeksi yang bermanfaat bagi Sarekat Islam, tetapi pengaruh golongan Samaun teristimewa pada Sarekat Sekerja mulai terasa sehingga mengakibatkan perpecahan menjadi dua macam Sarekat Sekerja, yaitu: Sarekat Sekerja yang menamakan dirinya revolusioner vakcentral, yang berkedudukan di Semarang, dengan pimpinan Samaun, dan Sarekat Sekerja yang berkedudukan di Yogyakarta dengan pimpinan Suryoprawoto dan Haji Agus Salim.

Perpecahan tersebut tidak saja pada Sarekat Pekerja akan tetapi juga sudah dirasakan dalam tubuh Central Sarekat Islam akibat dari adanya kritikan-kritikan yang sangat pedas dari Samaun dalam kongres ke V (1921). Perpecahan dapat diatasi

${ }^{20}$ Ibid, hal. 22 dengan kebijaksanaan dalam kongres, dengan cara semacam kompromi dari aliran-aliran dalam tubuh central Sarekat Islam, kemudian mengambil suatu keputusan bahwa aliran keagamaan yang diwakili golongan H. O. S. Tjokroaminoto dan aliran komunis yang diwakili golongan Samaun. ${ }^{21}$

\section{Timbulnya Perpecahan dalam Sarekat Islam}

Suasana kehidupan politik sesudah 1929 berbeda dengan kehidupan politik pada saat Sarekat Islam mulai berdiri. Pengalaman kehidupan berpolitik sepuluh tahun lebih memberi pandangan yang lebih luas. Pengaruh gerakan politik dari luar pun telah masuk. Demikian sikap Partai Sarekat Islam terhadap kerjasama dengan pemerintah Belanda perlu ditinjau kembali. Namun sesudah timbul perpecahan dalam tubuh Sarekat Islam akibat keluarnya golongan revolusioner sosialistis, yang dipimpin oleh Samaun dan penggabungan pelbagai Sarekat Islam lokal dengan partai Komunis Indonesia. Tetapi keuntungan ialah bahwa azas dan tujuan Sarekat Islam dapat diselamatkan dari penyelewengan Samaun yang jelas menganut paham komunis internasional.

Sarekat Islam berusaha memulihkan kekuatannya. Haji Agus Salim melancarkan gerakan PanIslamisme, maksudnya ialah unutk mencari hubungan dengan menghimpun kembali kekuatan Islam yang ada di Indonesia. Dengan

\footnotetext{
${ }^{21}$ Haji Agus Salim. Kelompok Politik Dalam Sarekat Islam. (Jakarta: Pustaka Sinar Harapan, 1997), hal. 27.
} 
melancarkan gerakan ini, maka Sarekat Islam mempunyai watak internasional. Kongras Al-Islam yang pertama diadakan di kota Cirebon dipimpin oleh Tjokroaminoto dan Agus Salim. Dalam kongres ini membahas masalah-masalah cabang dan perbeddaan-perbedaannya, yang lebih dikenal dengan sebutan Fu'ru dan Chilafijah. Dalam kongres tersebut dibicarakan pula masalah bagaimana mewujudkan kerjasama yang baik antara kaum muslimin.

Pada kongres Al-Islam yang kedua diadakan di Garut pada tahun 1922. Kongres ini dipimpin oleh Agus Salim membahas fungsi agama dan ilmu pengetahuan serta hubungan Islam dengan sosialisme, tidak lupa ia mengecam kapitalisme. Ia menyerukan betapa penting perstuan Islam dan fungsi majelis ulama. Kemudian beliau memimpin kongres Al-Islam luar biasa diselenggarakan di Surabaya yang dihadiri oleh para anggota Sarekat Islam, Muhammadiyah, dan golongan Islam lainnya. Agus Salim menguraikan nasionalisme berdasa Islam, memajukan nusa dan bangsa berdasar cita-cita Islam. Pada tahun 1925 diadakan kongres bersama antara Al-Islam dan Sarekat Islam di Yogyakarta. Tjokroaminoto menyarankan agar mulai diatur kehidupan rakyat di lapangan ekonomi, sosial dan kebudayaan menurut azas-azas Islam. Kemudian pada tahun 1926 diadakan lagi kongres Al-Islam yang keempat di Surabaya. Dalam kongres ini memutuskan untuk membentuk Muktamar Alam Islamy Fa'rus Hindis Sjariqah (M. A. I. H. S.) Keputusan hasil kongres bersama pada tahun 1925 di Yogyakarta menimbulkan pertentangan. Perentangan ini terletak hanya pada rencara tujuannya. Bila golongan $\mathrm{H}$. O. S. Tjokroaminoto-Agus Salim lebih menekankan pada azas keagamaan, sementara golongan SukimanSuryopronoto yang merupakan anggota Sarekat Islam lainnya lebih menekankan pada azas kebangsaan. Konflik ini menjadi sangat hebat yang mengakibatkan Dr. Sukiman dan kawan-kawannya mendirikan partai baru yang diberi nama Partai Islam Indonesia pada tahun $1923 .{ }^{22}$ dan tahun 1938 Dr. Sukiman yang diikuti oleh teman-temannya antara lain: Wibowo, Kasman, Singodimejo, Farid Ma'ruf, Abdul Kahar Muzakar dan K. H. Mas Mansyur keluar dari Partai Sarekat Islam. ${ }^{23}$

Perpecahan-perpecahan yang timbul dalam Partai Sarekat Islam ini erat kaitannya dengan soal kepemimpinannya. Yang mana kepemimpinan dalam Partai Sarekat Islam sangat rawan sebagai suatu organisasi politik. Perbedaan pendapat, perbedaan kepentingan dan ambisi pribadi lebih jelas apabila dibandingkan organisasi sosial pendidikan. ${ }^{24}$

\section{Daftar Pustaka}

Sartono Kartodirdjo, Sejarah Pergerakan Nasional dan Kolonialisme sampai

Nasionalisme Jilid 2 (Jakarta: Gramedia Pustaka Utama, 1993), hal. 6.

\footnotetext{
${ }^{22}$ Abu Hanifah. Renungan Perjuangan Bangsa Dulu dan Sekarang (Jakarta: Idayu, 1978), hal. 79

${ }^{23}$ Ibid, hal. 80 .

${ }^{24}$ Ibid, hal. 82.
} 
Abu Hanifah, Renungan Perjuangan Bangsa Dulu dan Sekarang (Jakarta: Yayasan Idayu, 1978), hal. 8, 9, 10.

Poespoprodjo W, Jejak-jejak Sejarah 19o8-1928. Terbentuknya Suatu Pola (Bandung: Remaja Karya, 1986), hal. 8

A. K. Pringgodigdo, Sejarah Pergerakan Rakyat Indonesia (Jakarta: Dian Rakyat, 1980), hal. 4.

Nugroho Notosusanto, Djoned Poespoprodjo, Marwari. Sejarah nasional Indonesia Jilid V(Jakarta: Balai Pustaka, 1966), hal.90.

Leirissa, R. Z. Terwujudnya Suatu Gagasan Sejarah Masyarakat Indonesia 1990-1950. (Jakarta: Akademi Presindo, 1985), hal. 37

Robert van Neil. Munculnya Elit Modern Indonesia. (Jakarta: Pustaka Jaya, 1984), hal. 121.

Slamet Mulyana. Nasionalisme Sebagai ModalPerjuangan Bangsa Indonesia. (Jakarta: BalaiPustaka, 1968), hal. 200.

M. Mansyur Amin. Sarikat Islam Obor Kebangkitan Nasional 19051944. (Yogyakarta: Kelompok IAIN Sunan Kalijaga, 1996), hal. 29.

M. C. Ricklefs. Sejarah Indonesia Modern . (Yogyakarta: Gadjah Mada University, 1992), hal. 252

Robert van Neil. Munculnya Elit Politik Modern Indonesia. (Jakarta: 1984), hal. 127.

Deliar Noer. Gerakan Modern Islam di Indonesia 190o-1942. LP3ES. (Jakarta: 1988). 
Amelz. H. O. S. Tjokroaminoto. Hidup dan Perjuangan. (Jakarta: Bulan Bintang), hal.96-97.

M. Dimyati. Sejarah Pergerakan Rakyat Indonesia. (Jakarta:Wijaya, 1951), hal. 16

M. Sidky Daeng Materu. Sejarah Pergerakan Nasional Bangsa Indonesia. (Jakarta: GunungAgung, 1996), hal. 25

Haji Agus Salim. Kelompok Politik Dalam Sarekat Islam. (Jakarta: Pustaka Sinar Harapan, 1997), hal.

27.

Abu Hanifah. Renungan Perjuangan Bangsa Dulu dan Sekarang (Jakarta: Idayu, 1978), hal. 79 